\title{
ANALISIS PENERAPAN AKUNTANSI PERSEDIAAN PADA BADAN KEPEGAWAIAN DAN PENGEMBANGAN SUMBER DAYA MANUSIA KABUPATEN MINAHASA
}

\author{
Aprillinda Angie Waworega ${ }^{1}$, Hendrik Manossoh $^{2}$, Steven J. Tangkuman ${ }^{3}$ \\ 1,2,3 Jurusan Akuntansi, Fakultas Ekonomi dan Bisnis, Universitas Sam Ratulangi, Jl.Kampus Bahu, Manado, \\ 95115, Indonesia \\ E-mail : waprillinda@gmail.com
}

\begin{abstract}
Human Resources and Human Resource Development Agency of Minahasa Regency is a supporting element of the Bupati's duties, led by the Head of the Agency, which is located below and the responsibility to the Regent through the Regional Secretary. Inventories are current assets in the form of goods or equipment to support activities operations of the government and the stuff that meant to be sold and / or delivered into service to the public. The purpose of this study is to know whether the implementation of inventory accounting applied to Human Resources Agency and Human Resource Development of Minahasa Regency is in accordance with Statement of Government Accounting Standard Number 05 (PSAP 05). The method used is interview and literature study. The methotds analysis data is used descriptive qualitative. The results of this study indicate that inventory accounting at Human Resources Agency and Human Resource Development of Minahasa Regency is mostly appropriate. However, inventory recognition with load approach has not used the accrual basis.
\end{abstract}

Keywords: Government Accounting, Inventory Accounting, PSAP No.05.

\section{PENDAHULUAN}

Di era globalisasi sekarang ini, menuntut sebuah perwujudan dari pemerintahan yang baik melalui sistem penataan kepemerintahan yang baik (good governance), yaitu dengan cara menciptakan transparansi, akuntabilitas, dan efektivitas serta efisiensi dalam pengelolaan keuangan negara. Sebagai usaha dalam mewujudkan suatu sistem penataan pemerintahan yang baik, harus dilakukan suatu inovasi yang baru di bidang akuntansi pemerintah, karena melalui proses akuntansi dapat menghasilkan informasi keuangan untuk berbagai pihak dan kalangan. Suatu perubahan yang terjadi dalam aspek akuntansi harus berdasarkan dengan asas yang berpengaruh seperti Standar Akuntansi Pemerintahan (SAP), yang bermaksud menuntun dalam proses menyusu dan menyajikan laporan keuangan pemerintah. Standar Akuntansi merupakan panutan dalam terciptanya laporan keuangan yang ditujukan kepada pihak-pihak eksternal organisasi yang mempunyai wewenang yang paling tinggi dalam kerangka akuntansi umum. Standar akuntansi sangat penting bagi yang menyusunan laporan keuangan dalam memutuskan data apa saja yang akan diberikan kepada pihak eksternal suatu institusi.

Standar akuntansi pemerintahan adalah dasar-dasar akuntansi yang sangat berguna untuk penyajian suatu laporan keuangan pemerintah (Bastian 2010:138). Sedangkan menurut Tanjung (2013) menyatakan bahwa Standar Akuntansi Pemerintahan adalah dasar pada saat menyusun dan melaporkan data keuangan pemerintah, yaitu Laporan Keuangan Pemerintah Pusat dan Laporan Keuangan Pemerintah Daerah. Pada 22 Oktober Tahun 2010, Pemerintah menerbitkan Standar Akuntansi Pemerintahan melalui Peraturan Pemerintah (PP) Nomor 71 tahun 2010 menggantikan PP Nomor 24 tahun 2005 mengenai hal yang sama. Dalam PP 71 tahun 2010 terdapat dua Standar Akuntansi Pemerintah, yaitu standar akuntansi pemerintahan berbasis akrual yang terdapat dalam lampiran I, dan Standar Akuntansi Pemerintah berbasis 
Kas Menuju Akrual yang terdapat pada lampiran II. Penerapan Standar Akuntansi Pemerintah Berbasis Akrual diterapkan untuk tahun anggaran 2010, dan apabila terdapat entitas yang belum siap menerapkan Standar Akuntansi Pemerintah Berbasis Akrual sebagaimana yang tertuang dalam lampiran I, maka dapat menggunakan Standar Akuntansi Pemerintah Berbasis Kas Menuju Akrual sebagaimana yang tertuang dalam lampiran II selama masa transisi. Standar Akuntansi Pemerintah Berbasis Akrual dapat diterapkan secara bertahap dari penerapan SAP Berbasis Kas Menuju Akrual menjadi Standar Akuntansi Pemerintah Berbasis Akrual. (PP No. 71 Tahun 2010).

Persediaan dalam pemerintahan sebagian besar bergantung pada karakter organisasi pemerintahan tersebut. Pengelolaan persediaan perlu dilakukan dengan baik mengacu kepada PSAP Nomor 05 tentang Akuntansi Persediaan yang terdapat pada Peraturan Nomor 71 tahun 2010 tentang Standart Akuntansi Pemerintah. Sebagai aset lancar, persediaan dianggap sebagai bahan habis pakai yang bersifat sulit untuk dipertanggungjawabkan. Pengelolaan persediaan perlu dilakukan dengan baik secara akuntabel dan transparan dan mengacu kepada PSAP Nomor 05 tentang Akuntansi Persediaan yang terdapat pada Peraturan Nomor 71 tahun 2010 tentang Standar Akuntansi Pemerintah. Pengelolaan persediaan yang teratur harus menjadi hal yang perlu diperhatikan oleh setiap instansi pemerintah agar dapat meminimalisir kekeliruan yang terjadi dalam pencatatan persediaan. Penumpukan barang digudang merupakan salah satu contoh kesalahan dalam pengelolaan persediaan yang kurang tepat. Hal ini menunjukkan kurang efektifnya kinerja instansi pemerintah dalam pelayanannya kepada masyarakat.

\section{TINJAUAN PUSTAKA}

Akuntansi Sektor Publik. Akuntansi sektor publik adalah aspek yang kemajuannya terjadi begitu cepat dalam beberapa tahun terakhir ini. Tuntutan pertanggungjawaban serta keterbukaan yang harus diterapkan pada instansi pemerintah terkait rincian penggunaan dana masyarakat menjadikan akuntansi sektor publik ini sangat diperlukan. (Nordiawan dan Heritanti, 2010:5).

Standar Akuntansi Pemerintah. Standar akuntansi pemerintah digunakan sebagai acuan dalam pemerintah pusat maupun pemerintah daerah untuk menyusun laporan keuangan. Karena pentingnya SAP dalam ruang lingkup pemerintahan, maka SAP harus dikembangkan lagi untuk menciptakan laporan keuangan yang baik dan benar. (Mahmudi, (2011:271).

Standar Akuntansi Pemerintah Berbasis Akrual. Standart akuntansi pemerintahan berbasis akrual adalah standar akuntansi pemerintah yang mengakui pendapatan, beban, aset, utang dan ekuitas dalam pelaporan finansial, berbasis akrual serta mengakui pendapatan, belanja dan pembiayaan dalam pelaporan pelaporan pelaksanaan anggaran berdasarkan basis yang ditetapkan dalam APBN/APBD. (Peraturan Pemerintah No. 71 tahun 2010). Berikut ini manfaat SAP BA menurut Riyanto dan Agus (2015:16) adalah : (a) menyampaikan informasi secara utuh mengenai posisi keuangan suatu instansi pemerintahan; (b) menyediakan fakta yang sebenarnya mengenaiapa yang menjadi hak dan kewajiban pemerintah; dan (c) mempermudah dalam mengevaluasi kinerja instansi pemerintahan yang berkaitan dengan biaya jasa layanan dalam mencapai tujuan laporan keuangan yang akuntabel.

Akuntansi Pemerintahan. Akuntansi Pemerintahan merupakan aspek akuntansi yang memiliki keterkaitan dengan suatu institusi pemerintahan yang tujuannya tidak untuk mencari laba. Walaupun seperti yang diketahui sebuah institusi pemerintah berukuran besar, namun dalam perusahaan ia termasuk dalam golongan lembaga mikro (Kustandi, 2015:1). Akuntansi Pemerintahan adalah sebuah jasa yang memberikan informasi data keuangan dari entitas pemerintah yang berguna dalam mengambil sebuah keputusan ekonomi sebagai suatu alternatif bagi pihak yang berkepentingan pada suatu entitas tersebut (Halim, 2015:143). 
Tujuan Akuntansi Pemerintahan. Berikut ini adalah tujuan akuntansi pemerintahan menurut Arif, dkk (2013:2) yaitu:

a. Akuntabilitas. Keuangan Negara harus diolah dengan sebaik mungkin dan dapat dipertanggungjawabkan.

b. Manajerial. Akuntansi Pemerintahan memberikan kesempatan untuk merencanakan dan menyusun APBD dalam mendukung kegiatan, strategi pembangunan yang dapat membantu tercapainya ketaatan pada peraturan undang-undang, efesiensi dan efektif.

Sistem Akuntansi Pemerintahan. Standar akuntansi pada sistem akuntansi yaitu untuk mengarahkan dan memberikan referensi yang menjadi dasar dalam pelaksanaan sistem akuntansi yang lengkap, relevan dan dapat dibandingkan. (Hariadi 2010:112).

Sistem Akuntansi Pemerintah Pusat. Sistem Akuntansi Pemerintah Pusat yaitu sebuah sistem yang mengelolah semua transaksi akuntansi keuangan yang mencakup kewajiban, aset dan ekuitas dana pemerintah pusat dan dapat menghasilkan informasi laporan keuangan dalam waktu yang tepat dan berguna bagi badan-badan di luar pemerintahan.

\section{Tujuan Sistem Akuntansi Pemerintah Pusat}

a. Mengatur seluruh asset pada pemerintah pusat dan instansi-instansi mulai dari proses mencatat hingga melaporkan laporan keuangan yang sesuai dengan proses akuntansi.

b. Memberikan data informasi secara akurat mengenai seluruh kegiatan dan anggaran.

Sistem Akuntansi Pemerintah Daerah. Sistem akuntansi pemerintah daerah menggambarkan gabungan dari subsistem yang memiliki tahap-tahap yang harus dilakukan dalam mengumpulkan data keuangan, dan kemudian dapat di proses menjadi laporan keuangan yang dapat diberikan kepada pihak internal maupun eksternal pemerintah daerah (Mahmudi 2016:19).

Tujuan Sistem Akuntansi Pemerintah Daerah. Berikut ini tujuan dari sistem akuntansi pemerintah daerah, yaitu : (a) menaikkan tingkat efesiensi dan efektivitas; (b) mendukung kegiatan harian; (c) meningkatkan laporan keuangan; (d) meningkatkan kualitas pengambilan keputusan; (e) meningkatkan akuntanbilitas finansial; dan (f) melindungi aset tetap pemerintah.

Akuntansi Persediaan. Definisi persediaan berdasarkan Pernyataan Standar Akuntansi Pemerintahan Berbasis Akrual (PSAP BA) No. 5 Paragraf 4 PP Nomor 71 Tahun 2010 adalah Aset lancar dalam bentuk barang atau perlengkapan yang dimaksudkan untuk mendukung kegiatan operasional pemerintah, dan barang-barang yang dimaksudkan untuk dijual dan/atau diserahkan dalam rangka pelayanan kepada masyarakat. Secara spesifik, tujuan utama entitas pemerintahan adalah untuk meningkatkan kesejahteraan masyarakat melalui pelayanan (Nordiawan, 2015:200).

Pernyataan Standar Akuntansi Pemerintahan Nomor 05 Tahun 2010. Peraturan Pemerintah Nomor 71 Tahun 2010 tentang Standar Akuntansi Pemerintahan (SAP) menyatakan bahwa SAP adalah prinsip-prinsip akuntansi yang diterapkan dalam menyusun dan menyajikan laporan keuangan pemerintah. PP 71 Tahun 2010 tentang Standar Akuntansi Pemerintahan terdapat dua Lampiran yaitu: Lampiran I yaitu tentang Standar Akuntansi Pemerintahan Berbasis Akrual dan Lampiran II yaitu tentang Standar Akuntansi Pemerintahan Berbasis Kas Menuju Akrual.

\section{METODE PENELITIAN}

Jenis Penelitian. Jenis penelitian yang diterapkan penulis pada penelitian ini adalah jenis penelitian kualitatif deskriptif. Jenis penelitian ini diuraikan secara sistematis tentang keadaan yang sesungguhnya yang terjadi mengenai Analisis Penerapan Akuntansi Persediaan pada BKPSDM Kabupaten Minahasa. 
Tempat dan Waktu Penelitian. Penelitian ini dilakukan pada BKPSDM Kabupaten Minahasa. Penelitian ini dilakukan pada tahun 2018 dan lamanya waktu penelitian yaitu 2 bulan, dimulai pada bulan juni hingga juli.

Jenis Data. Jenis data yang diterapkan penulis pada penelitian ini yaitu data kualitatif, yang berupa data wawancara dengan pihak BKPSDM Kabupaten Minahasa, yaitu : (1) Kasubag Kepegawaian, Umum dan Perlengkapan; dan (2) Kasubag Program Keuangan dan Pelaporan.

Sumber Data. Yang diterapkan dalam penelitian ini yaitu sumber data seperti berikut:

1. Data Primer. Data primer merupakan data yang diperoleh dengan cara melakukan survey lapangan secara langsung. Data primer dalam penelitian ini di dapat dengan meminta data-data yang diperlukan dan dari hasil wawancara.

2. Data Sekunder. Data sekunder merupakan data yang telah ada dan telah dipublikasikan kepada masyarakat pengguna data.

Teknik Pengumpulan Data. Teknik yang digunakan pada saat pengambilan data adalah:

1. Dokumentasi. Pengambilan data-data ini dilakukan melalui cara mengumpulan data mengenai hal-hal yang akan diteliti. Dokumentasi pada penelitian ini adalah transkrip hasil wawancara.

2. Wawancara. Mendapatkan data yang diinginkan dengan jalan mewawancarai pihak yang ada pada Badan Kepegawaian dan Pengembangan Sumber Daya Manusia Kabupaten Minahasa.

Metode Analisis. Analisis data yang digunakan penulis dalam penelitian ini :

a. Menguraikan proses akuntansi persediaan yang ada pada BKPSDM Kabupaten Minahasa dengan PSAP No.05 tentang persediaan.

b. Menganalisis proses akuntansi persediaan yang ada pada BKPSDM Kabupaten Minahasa Dengan PSAP No.05 tentang Persediaan.

c. Membandingkan proses persediaan yang ada pada BKPSDM Kabupaten Minahasa dengan PSAP No.05 tentang Persediaan.

d. Menganalisis poin-poin yang tidak sesuai pada proses akuntansi persediaan yang ada pada BKPSDM Kabupaten Minahasa Dengan PSAP No.05 PP No.71 Tahun 2010.

e. Menganalisa penyebab tidak sesuainya proses persediaan yang terjadi pada BKPSDM Kabupaten Minahasa dengan PSAP No.05 tentang Persediaan dari data hasil wawancara.

\section{HASIL PENELITIAN DAN PEMBAHASAN}

4.1. Hasil Penelitian

Klasifikasi Persediaan. Persediaan pada BKPSDM Kabupaten Minahasa dikelompokan menurut sifat dan fungsinya sesuai dengan kondisi kegiatan operasional entitas yang terdiri dari: (1) Persediaan Habis Pakai; (2) Bahan Meterial; dan (3) Persediaan Barang Lainnya.

Pengakuan Persediaan. Pengakuan persediaan yang ada pada BKPSDM Kabupaten Minahasa langsung diakui pada saat diterima persediaan sesuai dengan tanggal pencatatan masuknya barang dan ditandai dengan berita acara penyerahan barang setelah barang diterima. Berdasarkan dokumen-dokumen berita acara terima barang dan evaluasi berita acara terima barang dijadikan sebagai dasar tanggal pencatatan jurnal.

Pengukuran Persediaan. Pengukuran persediaan yang ada pada BKPSDM Kabupaten Minahasa dicatat sebesar harga beli. Sementara harga beli diketahui merupakan bagian dari harga perolehan. Untuk harga pokok produksi pada BKPSDM Kabupaten Minahasa sendiri tidak ada karena BKPSDM Kabupaten Minahasa tidak memproduksi barang, dan untuk barang yang diperoleh dengan hasil donasi sampai dengan desember 2017 BKPSDM tidak memperoleh barang dengan hasil donasi.

Beban Persediaan. BKPSDM Kabupaten Minahasa melakukan pencatatan persediaan menggunakan metode periodik. Maka pencatatan hanya dilakukan jika pada saat 
terjadinya penambahan, sehingga BKPSDM Kabupaten Minahasa tidak memperbarui jumlah persediaan. Pada akhir periode jumlah persediaan diketahui dengan melakukan stock opname. Hal ini berlaku untuk pencatatan persediaan untuk memenuhi keperluan yang ada pada sekretariat BKPSDM Kabupaten Minahasa.

Tabel 1. Penerapan Jurnal Beban Persediaan Pada BKPSDM Kabupaten Minahasa

\begin{tabular}{ccc}
\hline Keterangan & Debet & Kredit \\
\hline $\begin{array}{c}\text { Beban Persediaan } \\
\text { Persediaan }\end{array}$ & $\mathrm{Xxx}$ & $\mathrm{Xxx}$ \\
\hline
\end{tabular}

Pengungkapan Persediaan. BKPSDM Kabupaten Minahasa telah mengungkapkan kebijakan akuntansi yang digunakan dalam pengukuran persediaan, sebagaimana yang telah diungkapkan dalam pengukuran persediaan dijelaksan pada saat membeli barang persediaan, persediaan tersebut dicatat sesuai harga beli. Untuk poin kedua dan ketiga diungkapkan BKPSDM karena tidak adanya data persediaan yang memenuhi kriteria tersebut.

\subsection{Pembahasan}

Klasifikasi Persediaan. Persediaan pada BKPSDM Kabupaten Minahasa dikelompokan menurut sifat dan fungsinya sesuai dengan kondisi dalam aktivitas operasi entitas yaitu (1) Persediaan Habis Pakai, yaitu: ATK, Dokumen/Administrasi, Listrik dan alat elektronik, perangko, materai dan benda pos lainnya, alat kebersihan. (2) Bahan Meterial: Kawat, faksimili, internet, intranet, TV kabel, TV satelit. (3) Persediaan Barang Lainnya: pada BKPSDM tidak memiliki persediaan barang lainnya (untuk orang ketiga).

Pengakuan Persediaan. Pada akhir periode persediaan dicatat menurut inventarisasi fisik. Inventarisasi fisik persediaan dapat dilihat dari penghitungan dan pengukuran barang pada periode akhir pembukuan yang berguna untuk mengetahui jumlah persediaan. Setelah itu dapat disalin dalam pembukuan.

Pengukuran Persediaan. Persediaan sajikan sebesar biaya perolehan, jika persediaan didapat dengan cara melakukan pembelian sendiri. Biaya perolehan mencakup biaya pembelian, biaya pengangkutan, biaya penanganan dan biaya lain yang dapat dibebankan secara langsung pada perolehan persediaan. Potongan harga dan lainnya yang dapat mengurangi biaya perolehan persediaan apabila potongan tersebut dicatat dalam bukti pembelian, jika tidak dicatat maka akan diakui sebagai pendapatan.

Beban Persediaan. Pencatatan persediaan pada pemerintah diperbolehkan menggunakan metode perpectual maupun metode fisik (periodik). Pencatatan persediaan dengan menggunakan metode perpetual dengan pendekatan FIFO dikalkulasi menurut jumlah unit dipakai dikalikan dengan nilai rupiah per unit. Sedangkan pencatatan persediaan menggunakan metode perpetual, melakukan pencocokan dengan perhitungan fisik (stock opname). Apabila jumlah unit persediaan antara metode perpetual tidak sama dengan hasil perhitungan fisik maka diungggulkan pelaporan atas persediaan berdasarkan hasil perhitungan fisik (stock opname).

Pengungkapan Persediaan. Pengungkapan persediaan dalam laporan keuangan mengacu pada kebijakan akuntansi yang digunakan untuk pengukuran persediaan. Untuk poin selanjutnya yaitu poin kedua dan ketiga BKPSDM Kabupaten Minahasa tidak mengungkapkan hal tersebut dikarenakan tidak adanya data persediaan yang memenuhi kriteria dari poin kedua dan poin ketiga. Dalam hal tidak diungkapkannya poin kedua dan poin ketiga tidak menjadi masalah dalam pengungkapan persediaan karena pengungkapan persediaan tersebut disesuaikan dengan kondisi yang ada pada entitas yang bersangkutan. Sehingga dapat ditarik kesimpulan bahwa BKPSDM Kabupaten Minahasa tidak menyalahi PSAP No.05. 


\section{KESIMPULAN DAN SARAN}

\subsection{Kesimpulan}

Kesimpulan dari penelitian ini yaitu sebagai berikut:

1. Klasifikasi Persediaan pada BKPSDM Kabupaten Minahasa sudah sesuai dengan dengan PSAP No.05 yaitu persediaan Badan Kepegawaian dan Pengembangan Sumber Daya Manusia Kabupaten Minahasa digolongkan berdasarkan kesamaan ciri-ciri dan fungsinya dalam aktivitas BKPSDM.

2. Pengakuan persediaan BKPSDM Kabupaten Minahasa sudah sesuai dengan PSAP No.05 yaitu diakui pada saat barang diterima disertai dengan tanda terima barang.

3. Pengukuran Persediaan pada BKPSDM Kabupaten Minahasa sudah sesuai dengan PSAP No. 05 yaitu persediaan dicatat sesuai harga beli.

4. Beban persediaan pada BKPSDM Kabupaten Minahasa sudah sesuai dengan PP No.71 Tahun 2010 PSAP No.05. yaitu dengan menggunakan metode periodik.

5. Pengungkapan Persediaan BKPSDM Kabupaten Minahasa telah sesuai dengan PP No.71 Tahun 2010 PSAP No. 05.

\subsection{Saran}

BKPSDM harus mempertahankan akuntabilitas dan transparansi dalam menghasilkan laporan keuangan lebih khusus mengenai semua transaksi yang menyangkut persediaan karna peran akuntansi persediaan sangat penting dalam berjalannya kegiatan operasional suatu instansi.

\section{DAFTAR PUSTAKA}

Arnita, Kustandi. 2015. Pengertian Standar Akuntansi Pemerintahan. Edisi Perama. Salemba Empat. Jakarta.

Arif,dkk. 2013. Akuntansi. Akuntansi Keuangan, Akuntansi Anggaran, Akuntansi Perpajakan, Akuntansi Pemeriksaan, Akuntansi Persediaan. Akuntansi Pemerintahan, Tujuan Akuntansi Pemerintahan. Akuntansi Pemerintahan, Karakteristik Akuntansi pemerintahan. Syarat Akuntansi pemerintahan. Edisi Pertama. Salemba Empat. Jakarta.

Bastian, Indra. 2010. Akuntansi Sektor Publik Suatu Pengantar Edisi Ketiga. Erlangga. Jakarta.

Erlina, Rasdianto. 2013. Akuntansi Keuangan Daerah Berbasis Akrual. Brama Ardian. Medan.

Halim, Abdul. 2015. Akuntansi. Akuntansi Pemerintahan. Edisi 2. hlm. 143. Graha Ilmu. Jakarta.

Munawir, S. 2010. Analisis Laporan Keuangan. Edisi Keempat. Yogyakarta. Liberty.

Nordiawan, Deddi dan Hertianti, Ayuningtyas. 2010. Akuntansi Sektor Publik. Salemba Empat. Jakarta.

Peraturan Pemerintah Republik Indonesia Nomor 71 tahun 2010 Lampiran II Tentang Standar Akuntansi Pemerintahan.

Peraturan Menteri dalam Negeri Nomor 21. 2011. Perubahan Kedua atas Peraturan Menteri dalam Negeri. Nomor 13 Tahun. 2006. Pedoman Pengelolaan Keuangan Daerah.

Pemerintah Republik Indonesia, 2010. Peraturan Pemerintah Nomor 71 Tahun 2010 Pernyataan No.5 tentang Standar Akuntansi Berbasis Akrual.

Raharjaputra, Hendra, 2011. Manajemen Keuangan dan Akuntansi. Jakarta. Salemba Empat.

Ritonga, Taufiq. 2010. Akuntansi Pemerintahan Daerah. Sekolah Pascasarjana UGM. Malang

Tanjung, Abdul. 2013. Akuntansi Pemerintah Daerah Berbasis Akrual. Cetakan Kedua. Alfabeta. Bandung. 